Korner, A; (2011) Music of the Future: Italian Theatres and the European Experience of Modernity between Unification and World War One. EUR HIST Q , 41 (2) 189 212. 10.1177/0265691411399043. Downloaded at UCL Discovery: http://discovery.ucl.ac.uk/1305926

\title{
ARTICLE
}

\section{Music of the Future: Italian Theatres and the European Experience of Modernity between Unification and World War One*}

\author{
Axel Körner, UCL History Department, University College London
}

\begin{abstract}
This article challenges the common idea of Italy's obsession with Italian music, and with Verdi in particular, an image which supports stereotypes of Italians narrowly focussed on their own national culture, mentally sealed off from what is happening outside the peninsula. Starting from an analysis of the frequently rather mixed or even negative reception of Verdi's music in Italy, the article outlines the general crisis which affected Italian opera after Unification. One of the responses to this crisis was a remarkable internationalisation of the repertoire on the Italian stages. Taking music and opera as an example, the article demonstrates the extent to which Italy articulated its experience of modernity and nation building through a transnational exchange of ideas and a generous reception of European culture.
\end{abstract}

Keywords: Liberal Italy, Unification, Opera, Verdi

'The most important meeting point of the entire society, the only entertainment, is the theatre'. ${ }^{1}$ In these words a newspaper from Cagliari described in 1859 the role of the theatre in Italy's structures of municipal sociability. Following this description, our idea of nineteenth-century opera in Italy is often based on the image of bel canto and that of Verdi as the icon of the enthused audiences of the Teatro di San Carlo in Naples or the famous Teatro alla Scala in Milan. National and municipal cultures were closely interlinked and the historian of nineteenth-century Italy cannot study one without considering the other. However, while by the 1850s Verdi had become the most frequently performed Italian opera composer in Europe, he always had 'a difficult relationship with the Neapolitan public', accusing it of being 'fussy any time you present it with something different;' and between 1845 and 1887 not a single opera by Verdi was premiered in Milan. ${ }^{2}$ Notwithstanding the common association of the Risorgimento with opera, after Unification Italy's musical life entered into a profound crisis. Naples had problems attracting new productions and due to financial shortages the city's principal theatre remained closed for three successive seasons during the 1870s. Many Italian theatres did not survive the decline of public subsidies after Unification or were unable to attract impresari capable of operating on the dramatically reduced budgets. Many theatres in smaller cities no longer had a full 
season. The Pergola in Florence ceased regular performances of opera in 1877 and La Fenice in Venice remained closed for eleven out of 24 years. ${ }^{3}$

The Italian repertoire itself was in crisis. Rossini's last opera had been Guillaume Tell in 1829; Bellini had died in 1835; Donizetti in 1848. Mercadante was increasingly viewed as reactionary. The success of Verdi's Triologia (Rigoletto, II Trovatore, La Traviata) dates back to the 1850s. ${ }^{4}$ After Un ballo in maschera, in 1859, Verdi's wife feared that her husband 'had forgotten how to write music'. ${ }^{5}$ While Garibaldi fought for the liberation of the South, Verdi retired to the gentle life of a countryman. Eventually he wrote La forza del destino (1862), but for the Imperial Theatre of St. Petersburg, keeping Italy waiting for a revised version until 1869. Don Carlos (1867) was a French opera based on a German drama and written for the stages in Paris. Aida (1871) was commissioned by the Ismail Pasha, the Khedive of Egypt, and instead of celebrating the completion of the Risorgimento after the liberation of Rome, the work inaugurated the Cairo Opera House, built in connection with the opening of the Suez Canal. ${ }^{6}$ Two further Shakespeare operas followed many years later, Otello in 1887 and Falstaff in 1893. Hence, after Unification Verdi almost ceased to contribute to the consolidation of a national culture through opera. Meanwhile, Boito and Ponchielli were unable to match Verdi's reputation; and the Giovine scuola, with Puccini and Mascagni as its protagonists, took until the 1890s to revive Italian opera, generating rather mixed responses. In musical terms italianità was still difficult to define. The great connoisseur Thomas Mann observed in 1920 that, compared to Puccini, Verdi seemed almost German: less superficial and entertaining, more than just bellezza. The final scene of Aida was, for Mann, "ein italienischer Liebestod", an open reference to Wagner's Tristan und Isolde. ${ }^{7}$ Verdi had become a European more than an Italian composer.

Despite the apparent crisis of Italian opera after Unification, the theatre remained the focus of municipal sociability in Italy; and discourse on national identity was frequently articulated through references to music and opera - only that, increasingly, this music was no longer Italian by origin. This article challenges the common idea of Italy's obsession with Italian music, and with Verdi in particular, an image which contributes to widespread stereotypes of Italians narrowly focussed on their own national culture, mentally sealed off from what is happening outside the peninsula. The article will highlight the critical reception of Verdi's music in Italy as well as the general crisis which affected Italian opera after Unification. Within this context the article will then analyse the internationalisation of the repertoire on the Italian stages and demonstrate the extent to which Italy articulated its experience of modernity and nation building through a transnational exchange of ideas and a generous reception of European culture. Scholarship on nineteenth-century European nationalism overemphasises the role of national cultural production in the process of identity formation and should take into consideration the extent to which Europeans engaged with a culture that crossed the new national boundaries as easily as it travelled through Europe during the times of the Ancien Régime, thus contributing to the formation of transnational identities and of a trans-European cultural sphere. Verdi and Rossini marked the French and German theatre as much as Wagner and Massenet contributed to overcoming the crisis of Italian opera after Unification. 
For many people 'opera in Italy' still means Rossini, Bellini and Donizetti, the middle and later Verdi, and as a curiosity possibly Giordano's Andrea Chénier and Ponchielli's La Gioconda, a schedule completed during the fine secolo with Puccini, Leoncavallo and Mascagni. While this is an accurate reflection upon 'Italian opera in the world', it is a distortion of what was happening on the Italian stages between Unification and World War One. ${ }^{8}$ Although many of the major works of Rossini, Donizetti, Bellini and Verdi stayed in the repertoire throughout the nineteenth century, impresari as well as municipal administrators after Unification were keen to internationalise the repertoire of their theatres. In doing so they were able to build upon a remarkable tradition.

The German school in particular was popular among Italians. Between the late eighteenth and early nineteenth century German composers had enjoyed considerable success in Italian opera houses, including Johann Christian Bach, Johann Adolf Hasse, Adalbert Gyrowetz, Peter von Winter, Joseph Weigl and in particular Johann Simon Mayr, who wrote over seventy works for all the major Italian theatres and who counted Donizetti among his students. ${ }^{9}$ Mozart's operas stayed in the programme of La Scala and Rossini, during his early years in Lugo, learned from a German maestro, to be charged later 'with having adulterated the pure fount of Italian melody by bringing in far too much noisy German harmony'. ${ }^{10}$ Stanislao Mattei, one of Italy's most influential teachers of composition, was known for his love of Mozart and Haydn, while the popular Don Pasquale of his famous pupil Donizetti owed to Mozart and Schubert. ${ }^{11}$ At a time when Verdi already was an icon of Italian music, the works of the Prussian Hofkapellmeister and founder of the Vienna Philharmonic Otto Nicolai were hugely popular in Italy. ${ }^{12}$ Mazzini discovered Beethoven, Mozart and Wagner during his exile in London and greatly appreciated their work, which had a major impact on his Philosophy of Music of $1836 .^{13}$

Not just German music influenced Italians. In their development as composers, Mercadante, Marchetti and Verdi were all marked by French grand opéra. The 1830s are rightly regarded as the great season of Bellini and Donizetti in Italy. However, in 1838 La Scala opened its carnival season with Auber's La Muta di Portici, followed by the work of another 'foreign' composer, Ferdinand Hiller. ${ }^{14}$ Mercadante was interested in the Northern tradition of symphonic music. Along with a number of less formal symphonic pieces he wrote in 1861 a Sinfonia Garibaldi and as director of Naples' conservatory he organised performances of the Viennese classics, and of Weber, Auber and Offenbach. The following generation of Italian composers, Catalani, Giordano and Puccini, all learned from studying French and German scores. Not only the repertoire of Italian theatres was marked by its cosmopolitan ambition, also the casts were increasingly international. Verdi's most important soprano (and mistress), Teresa Stolz, was from Bohemia. In 1881 the influential Italian critic Francesco d'Arcais noted that during the Scala's current season 'only one, Tamagno, is Italian; the other three are foreigners: the soprano from Vienna, the baritone is French and the bass Polish. ${ }^{.15}$

While the great popularity of Verdi among audiences and major critics is beyond doubt, Italian responses to the compositore nazionale were not always positive. Emilio Treves' Universo Illustrato remarked in 1867 that Verdi had 'suffered more 
than one fiasco and often saw his merits questioned. ${ }^{, 16}$ His first published opera, Oberto, generated mixed responses in the press and Un giorno di regno was a complete failure. ${ }^{17}$ Only his third opera, Nabucco (1842), marked the beginning of Verdi's extraordinary career on the Italian stages. At La Scala and in Parma the premieres of Nabucco were an enormous success, repeated during the following decades throughout the peninsula. However, the Scala's first revival of the opera left the composer disappointed. In 1861, despite the patriotic enthusiasm for the current events, Genoa disapproved of Nabucco and stopped the performances after just two evenings. ${ }^{18}$

According to the arguments of Alberto Banti, the works of Rossini, Bellini and Donizetti, as well as the early Verdi, influenced the political ideas of the protagonists of Italy's national movement and had a direct impact on the transformation of the Risorgimento from a small sect into a political mass movement. ${ }^{19}$ However, if we look at the contemporary reception of these works we notice that many of them were rejected explicitly on patriotic grounds. Most prominent among those who criticised Rossini, Bellini and Donizetti was Giuseppe Mazzini, who in his Philosophy of Music pleaded for a radical departure of Italian music from its lyric tradition. ${ }^{20}$ Even Verdi, often seen as an icon of the Risorgimento, did not necessarily enjoy the approval of the Italian patriots. ${ }^{21}$ In January 1848, on the occasion of a performance of Ernani, the audience in Austrian occupied Mantua booed during the chorus of ' $g$ lory and honour to Charlemagne', because they saw the Emperor as a German. ${ }^{22}$ When shortly after the proclamation of the Republic in 1849 La Battaglia di Legnano was premiered in Rome it was understood as a celebration of patriotic freedom. This is despite the fact that the work is not overtly political or historical, focussing instead on a traditional triangle of love. In Bologna, after the liberation from the Papal regime, the opera was criticized because it did not properly reflect the 'patriotic affection' of Berchet's poem on the same subject. Instead, the work was perceived as a 'private story about love and jealousy'. ${ }^{23}$ Moreover, the author of the libretto, Salvadore Cammarano, was an official poet for the San Carlo in Naples, ${ }^{24}$ considered as one of the theatres most severely affected by censorship. Another opera often read in a political-national context, I Lombardi, was criticized by the Austrian censors for its failure to show respect for the faith, but not because it was too patriotic. Rather than referring to national sentiment, La Rivista di Firenze commented that the work satisfied 'the local pride of the Lombards'. ${ }^{25}$ The choice of Schiller for I Masnadieri (1847, based on Die Räuber) cannot necessarily be read as an overtly political statement. The choice of the libretto had much to do with Verdi's interest in literature and drama, and discussions with his librettist and translator of Schiller, Andrea Maffei. About the same time he developed an interest in Shakespeare. When preparing Macbeth he engaged closely with the translations of the Bolognese scholar Carlo Rusconi and studied August Wilhelm Schlegel's lectures on drama. During his long sojourns in Paris he became more and more fascinated with the effective representation of emotions and human psychology on stage, previously underdeveloped in Italian theatre. ${ }^{26}$ Verdi started controlling details of his productions almost fanatically, in this respect not dissimilar to Wagner's new approach to theatre. Printing the disposizioni sceniche for his operas, with details of the staging, was part of this project. His interest in dramatic action, more than politics and history, were at the centre of his work as composer. 
While it is not surprising that the Jesuit Civiltà Cattolica referred to Verdi's works 'as bad examples of taste in matters of politics, religion, or morality, ${ }^{, 27}$ there were other reasons too why some Italians did not like Verdi. Considering that one went to the opera for distraction and entertainment, numerous periodicals criticised the 'troppo assordante rumore' of Nabucco ${ }^{28}$ La Scala's first performances of La Forza del destino, I Masnadieri, Un Ballo in maschera and Aida were all marked by hissing and discontent among the audience. Writing to his friends after the Venice premier of $\mathrm{La}$ Traviata in 1853 the composer reported only 'Fiasco. Fiasco. Fiasco'. The 1857 premiere of Aroldo in Rimini went well, but Verdi was disappointed about the opera's reception in Bologna and Turin as well as in Naples, where the responses recalled the bitter lesson of the first performance of Alzira. ${ }^{29}$ In Bologna the end of the Papal regime did not silence Verdi's critics. ${ }^{30}$ On the occasion of Vittorio Emanuele's first visit the city's Teatro Comunale presented I Lombardi, followed during the autumn season by Un ballo in maschera - 'difficult music' with 'abstruse harmonic and melodic combinations', according to the city's principle newspaper, the liberal Monitore di Bologna. ${ }^{31}$ One of Bologna's most influential musical commentators, Enrico Bottrigari, opined that Un ballo in maschera lacked 'vigour and imagination.' About I due Foscari he wrote that the composer 'lacks thought and has no sense of melody'. Rigoletto was just too 'loud'; Stiffelio artificially 'forced'. ${ }^{32}$ On the occasion of crown prince Umberto's visit to Bologna the Comunale presented Simon Boccanegra, but the citizenry did not appreciate its 'abstruse and complicated' tunes and the local officer corps even refused to renew its subscription for the season. Bologna welcomed La forza del destino, but disliked the complicated libretto. The premiere of Verdi's Don Carlos was recognised as a great success for the city, but the national symbolism of the work, based on Schiller's drama, just bored Bottrigari. ${ }^{33}$ Elsewhere the reception of Don Carlos was also rather mixed. The editor of L'Universo Illustrato published an illustration of the setting, but concluded that 'the opera is too long; the music is monotone, a continuous flow of sadness.' Moreover, he was criticised for fashionable foreign influences: 'Even [Verdi] sacrifices himself to new idols, counting on the future....34 The reception at the Civico in Cagliari, a decade later, was equally mixed; and when the opera's revised Italian version returned to Naples in 1888, the local newspaper soon commented 'that the audience had enough of this opera. ${ }^{35}$ In 1881 Luisa Miller, another Schiller opera, provoked such discontent at Bologna's Teatro Dal Verme that the police had to intervene. ${ }^{36}$ Although most of the local newspapers praised the Aida of 1877, the frequent comparisons with the music of Wagner were not necessarily understood as a compliment and II Nuovo Alfiere called it 'un aborto d'un colosso'. ${ }^{37}$ On the question of why he was not at the theatre that night, the municipal civic engineer, Leopoldo Lambertini, replied to the famous writer Edmondo De Amicis 'because they are putting on this idiocy of Aida', continuing with a harangue against the composer's orchestration, his vulgarity and his choruses 'da osteria - stuff for heavy drinkers', he said, 'though one couldn't tell if the drinkers took it from Verdi or Verdi from the drinkers. ${ }^{38}$

As a consequence, many leading theatres staged most of Verdi's operas only once or twice, often with several years delay after the Italian premiere. Bologna's Comunale had to wait twelve years for La Battaglia di Legnano and then it was 
staged only once in the composer's life-time; Simon Boccanegra appeared once, five years after the premiere; Forza del destino once, seven years after the premiere in Saint Petersburg; Aida had to wait six years. Oberto, Un giorno di regno, Alzira and II Corsaro as well as Stiffelio and Jérusalem never made it onto the Comunale's stages during the composer's lifetime. Between 1870 and World War One there were many years without a single Verdi opera on the programme. ${ }^{39}$ For Naples we notice a similar pattern. Despite the theatre's outstanding role in the nation's musical life, Don Carlos had to wait four years for its first performance and La Forza del destino arrived only fifteen years after the prima. ${ }^{40}$ As Roger Parker remarks, in the years immediately following Verdi's death only about eight of his twenty-seven operas kept their places in the repertoire. 'All the early works, and quite a few of the later ones, had fallen out of fashion'. ${ }^{41}$

Hence, a simple association between Verdi and post-Risorgimento Italy is not an accurate reflection of what was happening in Italian theatres. In the view of many the Schaffenskrise of Italian opera-composers was part of a larger intellectual crisis which hit Italy profoundly during the years between 1871 and $1890 .{ }^{42}$ Although about 100 new Italian operas were staged during this period, the only works to make an impact were Boito's Mefistofele and Ponchielli's La Gioconda. None of them was able to revive the general euphoria with which the operas of the first half of the century had been greeted. In 1865 the Gazzetta Musicale di Napoli drew a disappointing picture of the decline in the musical life of the former capital, affecting the churches, the salotti of the nobility and the many theatres of Naples, which after Unification produced only prose and comedy. ${ }^{43}$ Even the San Carlo, despite having a higher endowment than most Italian theatres, had lost its ancient splendour. No singer, no ballerina equalled the level of the theatre's ancient tradition, L'Omnibus complained in $1867 .{ }^{44}$ According to the paper, Meyerbeer and Gounod could not possibly compete with Scarlatti, Paisiello and Cimarosa, even if there were hardly any Italian composers around who could take their place.

However, the contemporary accounts of the musical press seem exaggeratedly pessimistic, possibly the consequence of a general lack of orientation and confusion after the political and social turmoil of the past years. Looking in particular at the situation in Naples, the 1860s also saw the organisation of Italy's first Congresso musicale, the foundation of the Neapolitan Società del Quartetto and the city's first Concerti Popolari. ${ }^{45}$ Like Mercadante, Giuseppe Martucci had a strong interest in the symphonic repertoire, where Naples was able to triumph with one of Italy's best philharmonic orchestras. Musical life in Italy changed focus. Francesco d'Arcais remarked in 1881 that 'the musical life moves outside the theatres and the educated audience seeks more sophisticated artistic satisfaction in concerts. ${ }^{46}$ Rather than Italy's own eighteenth-century tradition of instrumental music, the repertoire which marked the new symphonic emphasis were the Viennese classics and German romantics - works which were still largely unknown to Italian audiences, but which had characterised the creation of the so-called 'musical museum' in the major urban centres of Central and Northern Europe since the first half of the nineteenth century. ${ }^{47}$ 
Returning to the article's opening quote, rather than speaking about Italy's musical life in national terms, it is important to consider its municipal specificities. As Francesco d'Arcais wrote in 1869, 'in our country, music lives a municipal life'. ${ }^{48}$ Meanwhile, this municipal musical culture was shaped through a constant dialogue with international intellectual and aesthetic developments from all over Europe. Starting from the cultural stagnation of the late Papal regime under Austrian occupation, during the fine secolo Bologna became one of the centres of Italy's musical avant-garde, playing a crucial role in the nation's opening towards the European repertoire. ${ }^{49}$ The city's Teatro Comunale had a major influence on the Italian opera scene as a whole; and as the example of Naples' concert-life shows, Bologna was not alone in promoting non-Italian music. At the 1884 Esposizione Italiana in Turin, conceived as a showcase of the Italian nation, the musical programme conducted by the young Giuseppe Martucci included works by Mozart, Beethoven, Mendelssohn, Schumann, Berlioz and Wagner, but no Verdi, despite the fact that symphonic concerts at the time frequently included extracts and arrangements of operatic works. The only Italian composers on the programme were the French citizen Luigi Cherubini; Domenico Scarlatti, who mainly worked in Spain and Portugal; and Luigi Boccherini, who spent most of his life in Spain, France and Austria, and then became court-composer of Friedrich Wilhelm of Prussia. ${ }^{50}$

Considering the role of opera in Italy's self-perception as a Kulturnation, the internationalisation of the theatres' repertoire after Unification seems even more remarkable than the sudden interest in French and German symphonic music. This trend began in the 1860s with the later works of Meyerbeer, continued after 1871 with Wagner, and marked all of the peninsula's major theatres with Gounod and Massenet during the following decades. Florence was in many respects a frontrunner in the internationalisation of the repertoire. First during the 1820s, then from the 1850s it had been 'la città meyerberiana per eccellenza'. ${ }^{51}$ Italy's most famous conductor around the time of Unification, Angelo Mariani, established Meyerbeer as an integral part of the repertoire, convincing the initially hesitant audience by his own professional genius and the continuously improving quality of the productions. The Milanese music critic Filippo Filippi hailed Meyerbeer for his fruitful references to different German tradition, from Bach and Handel to Beethoven and Weber. Mazzini admired him for moralising musical drama, 'making it an echo of the world and its eternal vital problem'. Soon, the German master of French grand opéra appeared in the popular open-air potpourris of municipal bands and during the commemorations for the revolution of $1848 .{ }^{52}$ Meyerbeer's posthumous L'Africaine was a spectacular success, first in Bologna (1865) and from 1866 in Milan, where the work was scheduled for three consecutive seasons. We can observe exactly the same phenomena in Naples: it was Meyerbeer, previously performed only sporadically, who since the 1860s marked the opening of the San Carlo towards the international repertoire, countering the crisis of Italian opera and offering Italians the opportunity to engage with Europe's aesthetic responses to the experience of the modern age. ${ }^{53}$ Cagliari, with a limited operatic experience, discovered most of Meyerbeer's works with a delay of several decades, but generously welcomed the German composer of grand opéra. ${ }^{54} \mathrm{~A}$ similar role was given to the new French masters. While Paris had been hesitant about the premiere of Gounod's Faust in 1859, the Italian premiere at La Scala was celebrated as a fantastic synthesis of French and German tastes. Even 
smaller Italian theatres such as the Rossini in Lugo performed Faust $(1869,1882)$, Massenet's Manon (1903) and Werther (1912). ${ }^{55}$ Many of the younger Italian composers were strongly influenced by the French and German schools: Stefano Gobatti, celebrated as the Italian Wagner; Arrigo Boito, the maestro of Mefistofele; and Alberto Franchetti, who had studied in Dresden and Munich before presenting Italy with his operas Asrael, Germania and Cristofo Colombo. Ferdinando Fontana, author of Puccini's Le villi and Franchetti's Asrael, stood for Italy's interest in Nordic mythology. Catalani's operas were influenced by Weber's romanticism and the fashion of German fairy-tale plots.

Obviously, this does not mean that the internationalization of the repertoire went without criticism. Traditional anti-Semitism, as well as modern ethnic and racial stereotypes, served to justify prejudice against 'foreign' music. In 1869 /I Monitore di Bologna remarked, bizarrely, that Mendelssohn was 'German and Jewish, a severe figure in the arts [...] one with his tribe, not one of us' ${ }^{56}$ Meyerbeer was described as 'più filosofo che maestro'. ${ }^{57}$ Ever since the 1871 Italian premiere of Wagner's Lohengrin influential critics and wide sections of the public expressed fears of a Germanisation of the Italian lyric tradition and in 1915 the Futurist composer Balilla Pratella published a manifesto Per una cultura della sensibilità musicale italiana, attempting to hold back Germanic and French influences on Italy's musical life. ${ }^{58}$ However, such voices were unable to reverse the internationalisation of the repertoire. In an age which saw cultural self-representation as a means to articulate national pride, the image emerging here is that of a nation which understood its cosmopolitan orientation as an integral part of its cultural value system, its intellectual ambition and its humanist legacy.

Who characterised Italy's turn to the European repertoire and to musical modernism more than any other composer was Richard Wagner, starting with Bologna's spectacular Italian premiere of Lohengrin in 1871, translated by Arrigo Boito. Milan presented its first Lohengrin two years later, Turin in 1876, Naples in 1881. While the performance at La Scala resulted in a fiasco, the success in Turin and particularly in Naples was as great as it was unexpected. ${ }^{59}$ The failure of Milan's Lohengrin had much to do with the ongoing fights between supporters of Verdi and those of Wagner, with the fact that the spectacular Italian prima of Aida was presented just a few months before Lohengrin. However, if the Milanese audience rejected Wagner in 1873, they warmly welcomed Weber's Freischütz just a few months earlier, demonstrating that they were not generally opposed to foreign imports. ${ }^{60}$ In many respects Venice remained in provincial isolation even after 1866. However, La Fenice staged Rienzi in 1874, Lohengrin in 1881 and Italy's first complete Ring under Angelo Neumann in 1883, shortly after the composer's death in the Lagoon.

The Italian capital of Wagnerism remained Bologna. Between 1871 and 1914 the Teatro Comunale had Wagner 23 times on the programme, while Verdi appeared only twelve times. During the same period Bellini, Donizetti and Rossini made it only eleven times onto the programme. ${ }^{61}$ It cannot be denied that in this respect the Teatro Comunale differed from other Italian theatres - the theatres of provincial cities as well as the major houses of the peninsula. But even in Naples, from the 1860s onwards, almost every season had one or two non-Italian operas on the programme; 
and not infrequently these 'foreign' operas represented the work that was most frequently performed during the season, like Halévy's L'ebrea in 1871 with 26 performances, compared to only nine performances of /I Trovatore and four performances of La Traviata. ${ }^{62}$ Moreover, the fact that a selection of bel canto and Verdi figured prominently on the programmes of most theatres does not necessarily mean that they were the most popular among the audience. For many smaller and medium-sized theatres they represented the usual daily business of the company, often performed by mediocre casts and with sets that appeared rather démodé. ${ }^{63}$ As a consequence of the poor quality of many of the revivals, the highlights of the season were the few more exceptional works and the new productions. One of the most spectacular events in the history of La Scala was the first performance, in 1870, of /I Guarany by the Brazilian composer Carlos Gomes. ${ }^{64}$

In Bologna, Lohengrin became the most frequently performed opera on the Comunale's schedule, well ahead of La Traviata and with Tristan following in third place ${ }^{65}$ And despite the cost involved in staging Wagner, the composer became a commercial success. In 1861 Ricordi refused Wagner a contract for the publication of his works in Italy, causing him to turn to Giovannina Lucca, who rather unexpectedly made a fortune with the German composer and became a major figure in Bayreuth circles. Lucca held the rights for the non-Italian composers David, Gounod, Halévy, Hérold, Meyerbeer, Flotow and Goldmark. Obviously, Ricordi's Gazzetta had no interest in writing favourably about Wagner. Its dislike was expressed through references to italianità and loyalty to Verdi, which contributed to the 1873 fiasco of Lohengrin at La Scala. Subsequently, very much to Ricordi's satisfaction, La Scala did not put any Wagner on until $1889 .{ }^{66}$ During that time the Comunale produced Tannhäuser in 1872, Rienzi in 1876, Der Fliegende Holländer the following year, its first complete Ring just days after Venice, in 1883, and Tristan, again in prima italiana, in 1888. Then Ricordi bought the publisher Lucca and his attitude to Wagner's work changed. ${ }^{67}$

Following a proposal by Bologna's first Democratic mayor, Camillo Casarini, Richard Wagner and Angelo Mariani, who had conducted Italy's first Lohengrin, were both given honorary citizenship. Wagner was elected a member of Bologna's Accademia Filarmonica, for a long-time seen as the bulwark of musical tradition. In 1876 the city's mayor Tacconi invited Wagner to visit Bologna and to attend a performance of Rienzi. ${ }^{68}$ A new production of Lohengrin, conducted by Luigi Mancinelli in 1882, ran for twenty performances. In addition to a performance of the Ring under Angelo Neumann and Anton Seidl in 1883, Wagner's death was marked with Bologna's own staging of Gotterdämmerung. Enrico Panzacchi spoke at the city's official commemoration. The poet Giosuè Carducci described his experience of the music he heard on the occasion to his lover Dafne Gargiolli in the following words:

'Isoldes Liebestod is for me the most extraordinary music I have ever heard. What greatness, what longing ... what holy pain! 'Walkürenritt': fantastic, beyond every human creation and at the same time a product of perfect technique. All this is a miracle. Finally, the opening of the Meistersinger, a treasure of music, not even to mention Tannhäuser...! $!^{69}$ 
Angelo Neumann described Bologna's performance of the Ring as a celebration for the Meister which went beyond anything he had ever seen in Germany. ${ }^{70}$ Based on a project Wagner himself had initiated shortly before his death, the Ring in Venice and Bologna was followed by performances in Rome, Turin and Trieste. The King attended the Roman Vorabend (Rheingold), Queen Margherita three of the four evenings. The Italian railway company supported the event with a $75 \%$ reduction on the transport cost for the entire cast. ${ }^{71}$ Five years later Bologna celebrated its Great Exhibition of 1888 with the Italian premiere of Tristan, conducted by Giuseppe Martucci, in the presence of the composers Arrigo Boito, Alfredo Catalani, Alberto Marchetti, Franco Faccio, the young Arturo Toscanini, the poets Giosuè Carducci and Gabriele D'Annunzio, the local Wagnerians Enrico Panzacchi, Luigi Torchi and Corrado Ricci, as well as diplomats, political representatives from all over Italy and the crème of the nation's musical press. ${ }^{72}$

In contrast to our contemporary image of Wagner, in nineteenth-century Italy the composer was largely associated with the Dresden barricades of 1848 , with the experience of political exile after the revolution, which he shared with so many Italian patriots of the Risorgimento, and with his Russian friend, the anarchist Mikhail Bakunin, who was deeply involved in the peninsula's revolutionary politics. Italy understood Wagner's theoretical texts on the 'music of the future' and the reform of the theatre as a response to and an application of Mazzini's Filosofia della musica of 1836; and until the 1890s it was mostly the Democratic and Republican Left which promoted Wagnerism in Italy. ${ }^{73}$ However, beyond these political connotations, the Italian debate on the composer reflects the search for a response to the experience of modernity in aesthetic modernism, as illustrated by an article on Lohengrin, published in the Gazzetta dell'Emilia two days before the opera's Italian premiere in Bologna:

'It is beyond doubt that our epoch is characterised by the fermentation of ideas, of battles between the most disparate principles - an epoch of transition, what conducts us straight to the great question, which is if reaction will prevail or if progress reaches apotheosis. ${ }^{74}$

According to the Gazzetta 'music of the future' stood for the opposite of everything the 'esclusivisti of the music of the past' referred to. ${ }^{75}$ Everywhere in Europe the followers of Wagner saw themselves as an avant-garde, as 'an intellectual cadre supporting works that it claimed were progressive and, by definition, controversial. ${ }^{176}$ Wagnerism was just as much celebrated in nineteenth-century Italy as it was in France, Belgium, England and Spain. ${ }^{77}$ The debate which arose in Italy from the confrontation with Wagner was not necessarily one about the music of a particular country or a particular composer, but about the concept of aesthetic progress and about the question whether the idea of progress and future could be associated with music. Wagner stood for a modernist aesthetic response to the experience of modern time, which contrasted with Italy's lyric tradition and the habitual role of theatre in society. Modernity was perceived as a phenomenon which concerned Europe as a whole.

Traditionally, aesthetic debates in Italian music theory were primarily concerned with melody and rhythm, the horizontal dimension of music. By the same token, 
participants in those debates often reacted with perplexity to the Germanic (and to some extent French) emphasis on developing music's vertical dimension through experimentation with the harmonic system and the symphonic structure of sound. ${ }^{78}$ Owing to the changing social context of opera in nineteenth-century Italy, the aesthetic expectations associated with music-theatre changed after Unification. As the influential critic Filippo Filippi remarked with reference to Verdi's Un ballo in maschera of 1859 , the great music of the first half of the century had been superseded by a new musical style which better fitted modern times, 'a brilliant reflex of the present civilisation, an eloquent and ideal commentary of our history'. ${ }^{79}$ For certain parts of the audience, as well as for the politicians in charge of the municipal theatres, the works of Rossini, Bellini and Donizetti no longer corresponded to the experience of societal change; and before long even Verdi only partly lived up to their expectations. The appeal of Wagner's operas, as before those of Meyerbeer, lay in the fact that they did not correspond to any established genre of the Italian tradition. The Rivista Bolognese di Scienze, Lettere, Arti e Scuole claimed that the listener thirsts 'for new things, new combinations, wishing to hear strong and innovative counterpoints, to be moved by original and unexpected melodramatic moments', words that resemble the theoretical writings of Baudelaire, Nietzsche and Wagner on modern aesthetics. ${ }^{80}$ Thus, new political and cultural actors, men like Bologna's Democratic mayor Camillo Casarini, the critic Enrico Panzacchi, the poet Gabriele D'Annunzio or the conductors Angelo Mariani and Giuseppe Martucci, were able to introduce Wagner as the composer of a new aesthetic, capable of generating meaning through new musical forms. Musica del futuro acquired a double meaning: on the one hand the term referred to a technically innovative apparatus; on the other, it stood for an aesthetic capable of making the contemporary experience of modernity meaningful. Modern time was marked by a sense that the past and the future no longer coincided. Through this new temporal dynamic the future was perceived as open and unpredictable. The music of the future had to be a music of infinity. ${ }^{81}$ It is only by exploring the reactions to both of these aspects of musica del futuro that we can fully understand this form of modernism in relation to Italy's experience of changing times.

A year after the premiere of Lohengrin the Italian parliament discussed the state of the country's music schools, with certain deputies voicing their concern about the presumed dominance of German innovation over Italian tradition. During the debate Casarini denounced Italy's 'ecstatic state of contemplative isolationism' in everything regarding music. In his view Italy was out of step with the general progress of modern times. With reference to the 'italianissimi Rossini and Verdi', he maintained that Italy's musical genius had always been inspired by contacts with ideas from abroad. Consequently, one could not deprive Italian students and audiences of Meyerbeer, Beethoven, Gounod or Mozart, and of Haydn's and Händel's oratorios. ${ }^{82}$

As a matter of fact, there was no reason to fear that Italians were deprived of foreign musical influences. In 1893 the Cronaca Wagneriana listed a total of 993 performances of Wagner in Italy, including 705 performances of Lohengrin. By 1900 the opera had been staged ninety-three times in Italy, and not only at La Scala (1873) or the San Carlo (1881), but also in smaller theatres like Treviso (1885), Piacenza (1889), Genoa (1890) or Cagliari (1899), and in cities not far from Bologna, 
like Ferrara (1889), Modena (1890) and Lugo (1900). The Teatro Massimo in Palermo presented its first Lohengrin within a year of its inauguration, in $1898 .^{83}$ Since 1871 Bologna had seen six stagings of Italy's most popular Wagner opera during this period, not only at the Comunale (repeated in 1882, 1887, 1889), but also at the Teatro Brunetti $(1884,1891) .{ }^{84}$ Luigi Mancinelli included Viennese classic in his concerti popolari, as well as works by Schumann, Brahms, French composers and extracts from Wagner's operas. Giuseppe Martucci, as director of Bologna's Liceo Musicale, introduced French, German as well as English and Irish composers. ${ }^{85}$ After the performance of Mendelssohn's Elias on the occasion of Bologna's Great Exhibition of 1888, the city witnessed in 1913 Bach's St.MatthewPassion, performed by the Berlin Philharmonic and the Sing-Akademie. ${ }^{86}$ Even an early exponent of Italy's Political Catholicism like the architect Alfonso Rubbiani remained 'profoundly touched' by this Protestant music: 'This is not l'art pour l'art, but art for religion', he wrote. ${ }^{87}$

Italy's rediscovery of historical music should not be misunderstood as aesthetic conservatism. The supporters of this trend were driven not only by an interest in the documentation of ancient music, but also in its aesthetics as an abstract means of expression which helped to formulate responses to the experience of modernity and aiming to establish a dialogic relation with Italy's own musical tradition. Italian modernism sought 'to mediate between the necessity of giving formal expression to the sense of alienation and futility of artistic practice', associated with the experience of modernity, 'and the desire to recuperate in a critical fashion the cultural tradition. ${ }^{88}$ The enthusiasts of ancient music were mostly those who at the same time introduced Italy to aesthetic modernism and the European avant-garde.

Italy's musical modernism clearly reached beyond Wagner. In 1905 Toscanini confronted Bologna with Humperdinck's Hänsel und Gretel, followed by stagings in Palermo and Genoa. ${ }^{89}$ Turin, in 1906, saw the Italian premiere of Strauss' Salome based on Oscar Wilde's drama, conducted by the composer himself. In 1908 the Italian premiere of Pelléas et Mélisande left a major impression on the Milanese audience; a similar success was Strauss' Rosenkavalier in $1911 .^{90}$ Turin celebrated the $50^{\text {th }}$ anniversary of Italy's Unification in 1911 with Claude Debussy. Bologna's autumn programme for the same year included Dukas' Arianna e Barbablù, on a libretto by Maeterlinck, and Mussorgsky's Godunov. ${ }^{91}$ Between 1901 and 1913 twenty-one Italian operas at the Comunale competed with nineteen 'foreign' works. During the same period the theatre presented five times an opera by Verdi, with altogether 39 performances, while Wagner appeared eleven times on the programme, with a total of 122 performances. Remarkably, it gave an opera by Puccini only twice: Tosca in 1900 and Madama Butterfly in $1905 .{ }^{92}$ During the Carnival 1894-95 La Scala presented six French operas: Reyer's Sigurd, Bizet's Pescatori, Manon and Werther by Massenet, Sansone by Saint-Saëns and Paladilhe's Patria. ${ }^{93}$ Bologna followed Naples in its discovery of Bizet, a trend soon picked up by a number of smaller theatres. ${ }^{94}$ In 1896 Milan premiered Henry VIII by Camille Saint-Saëns, followed by his Hélène in 1903. Samson reached Genoa in 1896, Bologna in 1899 and Palermo in $1907 .{ }^{95}$ Also at La Scala foreign imports outnumbered native composers and Milan's major prose theatres preferred French to Italian works. Paris during the fin-de siècle is often considered a European and 
cosmopolitan capital of culture. However, while Massenet was occasionally able to dominate the repertoire in France, Verdi never came close to a similar position in Italy. Italian culture during the decades around the turn of the century was profoundly cosmopolitan. Contrary to claims emphasising the role of opera in the nationalisation of European society, internationalisation was an important aspect of opera's aesthetic as well as its commercial success. ${ }^{96}$

Shortly before his death Wagner had determined that for thirty years his Festspielhaus should have the exclusive right to perform his last opera, Parsifal, a rule broken only by stagings in London (1884) and New York (1903 in German; 1904 in Yiddish). ${ }^{97}$ On the earliest permissible occasion, the 1st of January 1914, Bologna vied with Rome to present the first Italian Parsifal, a major event in the history of opera in Italy. Bologna got ahead only thanks to the decision to start the performance a few hours earlier, but it was beaten by Barcelona, which opened its Parsifal, fashioned as a Catalan national opera, at midnight on New Year's Eve. ${ }^{98}$ Milan presented its Parsifal on the $9^{\text {th }}$ of January. By this time the association of Wagner with the avant-garde had become less obvious, also in Italy. The Futurists rejected Parsifal for its historical theme as well as its aesthetic techniques. Admirers of Wagner in their early years, by the time of World War One Giovanni Papini and Filippo Tommaso Marinetti shouted 'down with Wagner; long live Stravinsky!'99

However, Bologna could still claim to be Italy's capital of musical modernism. Balilla Pratella introduced his own understanding of futurismo with his opera La Sina $d^{\prime}$ Vargöun, premiered at the Comunale in $1909 .{ }^{100}$ The following year Ottorino Respighi, a pupil of Martucci and Rimsky-Korsakov, presented his opera Semirama in Bologna. Rimsky-Korsakov's own opera The Golden Cockerel had been premiered at Turin's Teatro Regio. Shortly before its spectacular Parsifal, Bologna appointed Ferruccio Busoni as director of the Liceo Musicale. His appointment was perceived as a radical opening towards new aesthetic horizons, serving as another example for the international orientation of Italy's musical life during the period. ${ }^{101}$ In 1907 Busoni had published the first edition of Entwurf einer neuen Ästhetik der Tonkunst, a manifesto for a musical avant-garde. ${ }^{102}$ His opera Die Brautwah/ had been presented in Hamburg, a city at the time widely associated with aesthetic modernism. At the Musikhochschule in Berlin he later prepared the ground for Arnold Schönberg's appointment. Not only was Italy's musical life open towards the wider world, Italy's musical avant-garde, before World War One, enjoyed wide recognition well beyond the peninsula. Gustav Mahler, during his last concert at Carnegie Hall in New York, shortly before his death, conducted the world premiere of Busoni's Berceuse élégiaque, Martucci's second piano concerto, Leone Sinigalia's Ouverture Le barouffe Chiozzotte and the Intermezzi Goldoniani by Marco Enrico Bossi. ${ }^{103}$

Italy's musical modernism was understood as Futurism long before an aesthetic movement using this term established itself in Italy. And before Futurism became linked with aggressive nationalism, Italian aesthetic concepts of the future were European and cosmopolitan. The aesthetic concepts of Ardengo Soffici, Papini and Prezzolini were rooted in their experience of intellectual and artistic life in fin-desiècle Paris. As late as 1910 anarchists and syndicalists, who were generally sympathetic towards the Futurists, interrupted a lecture by Filippo Tommaso Marinetti 
in Milan with a chorus of Evviva l'internazionalismo. ${ }^{104}$ Openly discussing moments of crisis at home, Italians fostered their new identity through the embrace of an artistic and intellectual culture which they perceived as modern, but no longer as 'foreign'. The Italian engagement with (and assimilation of) European modernism obviously provoked intellectual and political controversy. Since the turn of the century, in line with the nationalistic credo of the time, certain sections of the avant-garde continuously referred to concepts of Italian primacy. However, the image of fine secolo Italy as a nation enclosed in its own traditions, obsessed with Verdi and proud of a history which set them apart from the rest of Europe, is utterly misleading.

The European experience of modernity gave rise to a number of aesthetically different modernisms. The engagement with and assimilation of modernism in the arts implies that recipients undertake subjective appropriations of the modernisms circulating in Europe, depending upon the particular socio-political context in which modernity is experienced. Esra Akcan speaks in this context about translation, a conceptual framework pointing to 'interaction' as well as to 'mutual dependence' between different national contexts. The trans-nationality of both modernity and modernism continuously produces 'new hybrids and dialectical relations', with the result that 'the definition of the local is always in flux'. ${ }^{105}$ Modernism was international and trans-national, but did not speak a single language, even when it was concerned with the same object of symbolic representation: the same modern opera or style could have different meanings depending upon the social context of its location. More specifically, in Bologna in 1871 the music of Lohengrin represented a stronger 'antithesis' of the past than was the case in Germany or France, where by that time the repertoire - including Wagner's own operas - had already evolved in a different direction. The perceived modernist content is always dependent on the specific context of reception. Ernst Bloch's concept of Ungleichzeitigkeit or non-synchronicity, as well as recent work on Metamorphoric Modernism (Russia), Provincial Modernities (Hamburg) or Multiple and / or Alternative Modernities (in the case of Fascist Italy or in Latin-America), presents similar phenomena. ${ }^{106}$

Within this perspective, the historiographical tradition of depicting Italian society as a deviation from general European developments, or as a people wholly absorbed in its own traditions, seems barely plausible. Italy's intellectual life at the turn of the century was at one with the wider European experience of modernity. When examining Italian identity, not only do we have to take account of regional diversity and strong municipal traditions, but also we should appreciate that Italian culture engaged closely with wider European experiences. Challenging the stereotypical idea of a nation obsessed with its own tradition and absorbed in its music, Italy's political, intellectual and cultural transformation during the nineteenth century was closely linked to the European experience of modernity, reflected in philosophical attempts at making modern change meaningful, in aesthetic debates and in particular in Italy's cosmopolitan approach to music and opera, an art-form which since the eighteenth century had occupied a central position in Italians' cultural self-representation.

\footnotetext{
* This article is the extended version of a paper presented at the 2008 Anglo-American Conference of the Institute of Historical Research, London. It develops out of research for a chapter of my book
} 
Politics of Culture in Liberal Italy. From Unification to Fascism (New York and London 2009). While the book's main focus is Bologna and the former Papal States, this article widens the perspective through research on theatres from different parts of the Italian peninsula (Milan, Turin, Naples as well as a number of smaller cities). For suggestions and for comments on earlier versions of this paper I am grateful to Patrick Chorley, John Davis, Maurizio Isabella, Nicola Miller, Roger Parker, Lucy Riall and Daniele Serafini, to two anonymous readers for $E H Q$, and to the Institute of Advanced Study in Princeton for offering me the opportunity to extend my research.

${ }^{1}$ Quoted in: Franco Ruggieri, Storia del Teatro Civico di Cagliari (Cagliari 1993), 139.

${ }^{2}$ For Naples: Julian Budden, The Operas of Verdi. Vol. 2. (Oxford 1992), 12. See also Carlotta Sorba, 'To Please the Public: Composers and Audiences in Nineteenth-Century Italy', Journal of Interdisciplinary History, Vol. 36/4 (2006), 595-614, 601. For Milan: Frank Walker, The Man Verdi. (London 1962), 128. Since the premiere of Giovanna d'Arco Verdi had been so 'thoroughly disgusted with the way Merelli was producing his works there' that he refused any collaboration with the theatre. The only exceptions were the premieres of the Milan premieres of the revised versions of La forza del destino (1869), Simon Boccanegra (1881) and Don Carlos (1884).

${ }^{3}$ John Rosselli, The Opera Industry in Italy from Cimarosa to Verdi. The role of the Impresario, (Cambridge 1987), 78. Marco Santoro, 'Imprenditoria culturale nella Milano di Fine Ottocento', in Carlotta Sorba (ed.), Scene di fine Ottocento. L'Italia fin de siècle a teatro (Rome 2004), 101-46, $115 \mathrm{f}$. Lorenzo Bianconi and Giorgio Pestelli, Storia dell'opera italiana. Vol.4 (Turin 1987), 180. Also Körner, Politics of Culture, op.cit, chpt.3.

${ }^{4}$ Les Vêpres Siciliennes (1855) was a French opera written for Paris. Simon Boccanegra was first performed in Venice (1857), but had to wait until 1881 to appear in revised version at La Scala. Aroldo (1857), based on his earlier Stiffelio, was written for Rimini.

${ }^{5}$ Giuseppina Verdi, 15 October 1859, quoted in Alessandro Luzio (ed.), Carteggio Verdiani (Rome 1935), 64-6, 66.

${ }^{6}$ Budden, op.cit., Vol.3, 163 f. Also Paul Robinson, 'Is Aida an orientalist Opera?', Cambridge Opera Journal, Vol. 5/2 (1993), 133-40, 134.

${ }^{7}$ Fabrizio Della Seta Della Seta, Italia e Francia nell'Ottocento (Turin 1993), 178. Alexandra Wilson, The Puccini Problem. Opera, Nationalism and Modernity (Cambridge 2007). Elisabeth Galvan, 'Thomas Mann in Italia. Thomas Mann, Gabriele D'Annunzio e Giuseppe Verdi', in Arnaldo Benini and Arno Schneider (eds), Thomas Mann nella storia del suo tempo. Firenze: Passigli Editori, 2004, $151-171,163 \mathrm{f}, 166$.

${ }^{8}$ For the distinction between 'opera in Italy' and 'Italian opera in the world' see John Rosselli's review of David Kimbell, Italian Opera (Cambridge 1991) in Cambridge Opera Journal, 4/1, (1992), 87-90.

${ }^{9}$ Heinz Gärtner, John Christian Bach, Mozart's Friend and Mentor (Portland, Oregon 1994), 109 sq. Mark Everist, Giacomo Meyerbeer and Music Drama in Nineteenth-Century Paris. (Aldershot 2005), 87 f. On Donizetti's German influences see Carlo Gatti, Il Teatro alla Scala nella storia e nell'arte (1778-1963) (Milan 1964), $70 \mathrm{f}$

${ }^{10}$ Gatti, op.cit., 61-112. John Rosselli, Music and musicians in 19th Century Italy (London 1991), 52.

${ }^{11}$ Enrico Panzacchi, 'Gioacchino Rossini. Discorso detto a Pesaro nell'aula grande dell'Istituto Rossini, per il centenario rossiniano', in: idem, Nel Mondo della musica (Florence 1895), $116 \mathrm{f}$.

${ }^{12}$ For an overview of Nicolai's performances in Italy see Thomas G. Kaufman, Verdi and his major contemporaries. A selected chronology of performances and casts (New York 1990), 111-14.

${ }^{13}$ Dennis Mack Smith, Mazzini (New Haven 1994), 26.

${ }^{14}$ Gatti, op.cit., $94 \mathrm{f}$.

${ }^{15}$ On the complex relationship between Stolz, Verdi and Mariani see John Rosselli, The Life of Verdi (New York 2000), 135-41; Walker, op.cit., 283 sq; Hans Busch (ed.), Verdi's Aida. The History of an Opera in letters and documents (Minneapolis 1978), 211 ff, 220. Francesco d'Arcais, 'Rassegna Musicale', Nuova Antologia, sec. ser. Vol.XXV (1881), 707-18, 710.

${ }^{16}$ L'Universo Illustrato. Giornale per tutti, 1/36 (1867), 577.

${ }^{17}$ Mary Jane Phillips-Matz, Verdi. A Biography (Oxford 1993), 94, 109. Budden, op.cit., Vol. 1, 50.

${ }^{18}$ The most detailed account of the opera's historical context is Roger Parker's introduction to the new edition of Verdi's works: The Works of Giuseppe Verdi. Series I. Operas. v.3 Giuseppe Verdi, (Nabucodonosor: dramma lirico in four parts), ed. by Roger Parker. Chicago / Milan: The University of Chicago Press / G. Ricordi \& C., 1987, XI-XXVI. On the success of the Milanese premiere PhillipsMatz, op.cit., 116 f, 136-9. G. B. Valebona, Il Teatro Carlo Felice. Cronistoria di un secolo, 1828 1928 (Genova 1928), 144, 170. The result in 1870-71 was not much better, with seven evenings only. ${ }^{19}$ Alberto M. Banti, La nazione del Risorgimento. Parentela, santità e onore alle origini dell'Italia unita (Turin 2000), 45. More recently Carlotta Sorba, 'Il Risorgimento in musica: l'opera lirica nei 
teatri del 1848', in: Alberto M. Banti and Roberto Bizzocchi (eds), Immagini della nazione nell'Italia del Risorgimento (Rome 2002), 133-156. For a critique of Banti’s operatic canon see Axel Körner, 'The Risorgimento's literary canon and the aesthetics of reception: some methodological considerations', Nations and Nationalism, 15/3 (2009), 410-18.

${ }^{20}$ Giuseppe Mazzini, Filosofia della musica. Marcello De Angelis, ed. (Rimini 1977). Franco Sciannameo (ed.), Giuseppe Mazzini's Philosophy of Music (Lewitson 2004).

${ }^{21}$ For a critique of a patriotic reading of Verdi see Roger Parker, 'Arpa d'or dei fatidici vati'. The Verdian patriotic chorus in the 1840s (Parma 1997). Idem, Leonora's Last Act. Essays in Verdian Discourse. (Princeton 1997). Mary Ann Smart, 'Liberty On (and Off) the Barricades: Verdi's Risorgimento Fantasies', in: Albert Russell Ascoli and Krystyna von Henneberg (eds), Making and Remaking Italy. The Cultivation of National Identity around the Risorgimento. (Oxford 2001), 103-18. Also William Ashbrook, 'The Nineteenth Century: Italy', in: Roger Parker (ed.), The Oxford History of Opera (Oxford 1996), 114-37, 128. John A. Davis, 'Opera and Absolutism in Restoration Italy, 18151860’, Journal of Interdisciplinary History, Vol.36/4 (2006), 569-94, 570 ff, 577; Stefano Castelvecchi, 'Was Verdi a Revolutionary?', ibid., 615-20, 619. For the traditional view of Verdi as the bard of the Risorgimento: George Martin, 'Verdi and the Risorgimento', in: William Weaver and Martin Chusid (eds), The Verdi Companion (New York 1979), 13-41. Gatti, op.cit., 96-112, 116 ff. ${ }^{22}$ Phillips-Matz, op.cit., $237 \mathrm{f}$.

${ }^{23}$ Mary Ann Smart, "Verdi, Italian Romanticism and the Risorgimento", in: Scott L. Balthazar, ed., The Cambridge Companion to Verdi. Cambridge: Cambridge University Press, 29-45, 31, 39. For the Bologna performance see Monitore di Bologna, 28 December 1860.

${ }^{24}$ Fabrizio della Seta, "New currents in the libretto", in: Scott L. Balthazar, ed., The Cambridge

Companion to Verdi. Cambridge: Cambridge University Press, 2004, 69-87, 74.

${ }^{25}$ Phillips-Matz, op.cit., 143, 145.

${ }^{26}$ Fabrizio della Seta, Italia e Francia nell'ottocento. Storia della musica, 9. Torino: EDT, 1993, 226. Alessandro Roccatagliati, “The Italian theatre of Verdi’s day”, in: Scott L. Balthazar, ed., The Cambridge Companion to Verdi. Cambridge: Cambridge University Press, 2004, 15-28, 21.

${ }^{27}$ Andreas Giger, 'Social control and the censorship of Giuseppe Verdi's operas in Rome (18441859)', Cambridge Opera Journal, Vol.11/3 (1999), 233-66, 233.

${ }^{28}$ See for instance La Farfalla and Teatri Arti e Letteratura, quoted in Verdi (ed.), op.cit., 3 f; Mondo Illustrato, quoted in Rubens Tedeschi, 'L'Opera italiana', in Storia d'Italia (Turin 1973-1976), Vol.5/2, 1141-80, 1171.

${ }^{29}$ Phillips-Matz, op.cit., 158 f, 179. Gatti, op.cit., 101. Budden, op.cit., Vol. 2, 339. Alzira and Il Corsaro were among the few works for which the publisher Lucca held the rights, but they caused the firm a major financial loss. Walker, op.cit., 123.

${ }^{30}$ Between 1860 and 1870 Verdi was seventeen times on the programme of the Comunale (including revivals), but already during the second half of the 1860s the interest in Verdi declined. At the time Donizetti was the second most popular composer, followed by Meyerbeer. Rossini (as well as Bellini) appeared only three times on the programme. The main sources for the repertoire of Bologna's Teatro Comunale are Lamberto Trezzini (ed.), Due secoli di vita musicale. Storia del Teatro Comunale di Bologna (Bologna 1987). Luigi Bignami, Cronologia di tutti spettacoli rappresentati nel gran Teatro Comunale di Bologna dalla solenne sua apertura 14 maggio 1763 a tutto l'Autunno del 1880 (Bologna 1880). See also Marina Calore, Bologna a Teatro: l'Ottocento (Bologna 1982). Mirtide Gavelli and Fiorenza Tarozzi (eds), Risorgimento e Teatro a Bologna, 1800-1849 (Bologna 1998).

${ }^{31}$ Monitore di Bologna, 5 October 1860.

${ }^{32}$ Enrico Bottrigari, Cronaca di Bologna 1845-1871. Aldo Berselli, ed. (Bologna 1960-1963), Vol.3, 115. Verdi's own comment on I due Foscari to his Milanese friend Toccagni is quoted in Walker, op.cit., 124. On Bologna's response to Verdi see also Panzacchi, in: Il Monitore di Bologna, 12 October 1875. Also Enrico Panzacchi, A Proposito del Tannhaeuser rappresentato a Bologna nell'autunno 1872 (Bologna 1872), 25.

${ }^{33}$ Bottrigari, op.cit., Vol.3, 219, 494; Vol.4, 79. Monitore di Bologna, 7 October 1861. Archivio Storico Comunale di Bologna (ASCB), Carteggio Amministrativo (CA), 1861, Deputazione dei pubblici spettacoli, Miscellanea, Ufficiali del Battaglione di Bologna al Cav. Delegato per i pubblici spettacoli, 8 November 1861. Verdi (ed.), op.cit., 178, 181, 188 f. Monitore di Bologna, 28 October 1867. See also Lionello Levi, 'Due secoli di vita musicale', in: Trezzini (ed.), op.cit., Vol. 1, 1-44, 15. Cormac Newark, 'In Italy we don't have the means for illusion: Grand opéra in nineteenth-century Bologna', Cambridge Opera Journal, Vol.19/3 (2007), 199-222.

${ }^{34}$ E.T. [Emilio Treves] in: L'Universo Illustrato, Vol.2/26 (1868), 426, $432 \mathrm{f}$. 
${ }^{35}$ Quoted in: Renato di Benedetto, 'L’Ultimo trentennio dell'ottocento', in: Raffaele Ajello et al. (eds), Il Teatro di San Carlo (Naples 1988), Vol.1, 205-36, 223. Ruggieri, op.cit., 153.

${ }^{36}$ Gazzetta dell'Emilia, 23 September 1881.

${ }^{37}$ Verdi (ed.), op.cit., 201-31, for the quote see 210.

${ }^{38}$ Corrado Ricci, Riccordi Bolognesi (Bologna 1924), 31-5. On Lambertini see also Francesco Vatielli, Cinquanta anni di vita musicale a Bologna (1850-1900) (Bologna 1921), 32.

${ }^{39}$ Verdi (ed.), op.cit., VIII ff. For an early historical reflection on Bologna's Verdism see Felice

Romani, 'Alcuni cenni storici sull'arte musicale e della danza', in: Bignami, op.cit., 5-12, 9.

${ }^{40}$ Renato di Benedetto, 'L'Ultimo trentennio dell'ottocento', in: Ajello et al. (eds), op.cit., Vol.1, 205$36,212 \mathrm{f}$.

${ }^{41}$ Roger Parker, The New Grove Guide to Verdi and his Operas (Oxford 2007), VII.

${ }^{42}$ See for instance Benedetto Croce, Storia d'Italia (Rome and Bari 1928), 133.

${ }^{43}$ Quoted in: Renato di Benedetto, 'L'Ultimo trentennio dell'ottocento', in: Ajello et al. (eds), op.cit., Vol.1, 205-36, 207.

${ }^{44}$ Quoted in: di Benedetto, op.cit., $209 \mathrm{ff}$.

45 The Società del Quartetto in Turin, established in 1854, followed the example of similar associations in Vienna, Leipzig and Berlin, organising popular symphonic concerts, for which the cheapest ticket was only about half the cost of the cheapest ticket for the opera. The Società del Quartetto in Florence dated back to 1861 and from the very beginning it appealed to a wider audience, organising concerts in the afternoon and in public theatres. Bologna's Società del Quartetto, founded in 1877, organized concerts in the palace of Count Camillo Pizzardi. Alberto Basso, Storia del Teatro Regio di Torino. (Turin 1976), Vol.2, 343. Rosselli, Music and musicians, op.cit., 124 ff. Francesco Flora, 'Il risorgimento e l'età Carducciana', in: Bologna e la cultura dopo l'Unità d'Italia (Bologna 1960), 41123, 121. Bottrigari, op.cit., Vol.3, 132.

${ }^{46}$ Francesco d'Arcais, 'Rassegna Musicale', Nuova Antologia, sec. ser., Vol.25/4 (1881), 707-718, 716. In Rome symphonic music was performed mostly through Ettore Pinelli’s Società Orchestrale: Francesco d'Arcais, 'Rassegna Musicale', Nuova Antologia, sec. ser., Vol.27/12 (1881), 695-706, 700. ${ }^{47}$ By 1827, the year of Beethoven's death, $75 \%$ of the repertoire in Vienna was written by composers who were no longer alive. By 1850 the Leipzig Gewandhaus repertoire reached a percentage of over $60 \%$ and the orchestra of the Paris Conservatoire of $90 \%$. From the 1870 s $80 \%$ of the London Philharmonic Society's repertoire was by composers who were no longer alive. See William Weber, 'Wagner, Wagnerism, and Musical Idealism', in: David C. Large and William Weber (eds), Wagnerism in European Culture and Politics (Ithaca and London 1984), 28-71, 38, 49. William Weber, Music and the Middle Class. The Social Structure of Concert Life in London, Paris and Vienna (New York 1975). Idem, 'Mass culture and the reshaping of European musical taste, 1770-1870', International Review of the Aesthetics and Sociology of Music, Vol.3/1 (1977), 5-22, 6.

${ }^{48}$ Francesco d'Arcais, 'Rassegna Musicale', Nuova Antologia, Vol.4/2 (1869), 402-7, 402. Crucial in discussing the municipal focus of Italy's musical life is Sorba, Teatri op.cit.

${ }^{49}$ On the concept of avant-garde see Reinhard Kannonier, ,Gesellschaftliche Moderne und künstlerische Avantgarde', Sociologia Internationalis. Beiheft 1: Gesellschaft und Musik. Wege zur Musiksoziologie (1992), 115-30, 118 sq. Not unproblematic: Matei Calinescu, Five Faces of Modernity (Durham 1987), 95 sq. For a critique of the concept in Italy see Luca Somigli and Mario Moroni (eds), Italian Modernism. Italian Culture between Decadentism and Avant-Garde (Toronto and London 2004), 9; and more generally Carl Dahlhaus, Schönberg und andere. Gesammelte Aufsätze zur Neuen Musik (Mainz 1978), $40 \mathrm{f}$.

${ }^{50}$ Folco Perrino, Giuseppe Martucci (Novara 1992-1996), Vol. 2, 131.

${ }^{51}$ Marcello De Angelis, Le carte dell'impresario: melodrama e costume teatrale nell'ottocento. (Florence 1982), 21, 81.

${ }^{52}$ Mack Smith, op.cit., 26. On Meyerbeer's role in Italian theatre see also Everist, op.cit., 177. Heinz and Gudrun Becker, Giacomo Meyerbeer. A Life in Letters (London 1989), 12 ff. Alessandro Roccatagliati, 'Opera, Opera-Ballo e Grand Opéra: Commistioni stilistiche e recezione critica nell'Italia Teatrale di Secondo Ottocento (1860-1870)', Studi di Musica Veneta. Opera \& Libretto, Vol.2 (1993), 283-349, 300. Michael Wittmann, 'Meyerbeer and Mercadante? The reception of Meyerbeer in Italy', Cambridge Opera Journal, Vol.5/2 (1993), 115-132, 117. Monitore di Bologna, 23 November 1861, 4 August 1864.

53 di Benedetto, op.cit., 214.

${ }^{54}$ Ruggieri, op.cit., 137-68.

${ }^{55}$ Gatti, op.cit., 134. Michele Rossi, Cento Anni di Storia del Teatro di Lugo. - La Patria di Rossini. (Lugo 1916), 53. 
${ }^{56}$ Monitore di Bologna, 11 June 1869. This is despite the fact that later prejudice against Mendelssohn frequently referred to the supposedly superficial character of his music: Andreas Eichhorn, Felix Mendelssohn Bartholdy (Munich 2008), 100 sq.

${ }^{57}$ Teatri, Arte e Letteratura, quoted in: Vatielli, op.cit., 14 f. See also Monitore di Bologna, 24 March and 10 November 1869. Similar debates go back to the 1850s: Roccatagliati, op.cit., $293 \mathrm{ff}$.

${ }_{58}$ Balilla Pratella, Musica Italiana. Per una cultura della sensibilità musicale italiana (Bologna 1915). For the Italian debate on Wagner see Körner, Politics of Culture, op.cit., chpt.9.

${ }^{59}$ The Scala staged Wagner twenty-four times before the war, but the total number of performances was much higher than in Bologna. Giogio Manera and Giuseppe Pugliese (eds), Wagner in Italia (Venice 1982). Mario Baccaro, 'L’Opera di Wagner a Napoli', in: Felice de Filippis (ed.), Cento Anni di Vita del Teatro di San Carlo, 1848-1948. (Naples 1948), 89-92, 89.

${ }^{60}$ Gatti, op.cit., $143 \mathrm{f}$.

${ }^{61}$ Bellini and Donizetti appeared four times each, Rossini twice.

${ }^{62}$ Carlo Marinelli Roscioni (ed.), Il Teatro di San Carlo. La cronologia 1737-1987 (Naples 1987), 382.

${ }^{63}$ Verdi's friend Emanuele Muzio described the maestro's anger when I Lombardi returned for the first time to La Scala - he 'shouts as if in desperation; he stamps his feet so much that he seems to be playing an organ with pedals; he sweats so much that drops fall on the score.' Quoted in Walker, op.cit., 127.

${ }^{64}$ Gatti, op.cit., 142.

${ }^{65}$ This last figure regards the period 1882-1950, covering the modern history of the theatre from the year in which the exact number of performances per season is known. Lohengrin was played on 76 evenings, La Traviata on 57 and Tristan 54 evenings.

${ }^{66}$ Marion S. Miller, 'Wagnerism, Wagnerians and Italian Identity', in: Large and Weber (eds), op.cit., 167-97, 174, 180 f. Gatti, op.cit., 141. Irene Piazzoni, 'Il governo e la politica per il teatro: tra promozione e censura (1882-1900)', in: Sorba (ed.), op.cit., 61-100, 69 f. Although Verdi pronounced himself occasionally against 'the invasion of foreign art', on other occasions he also showed an interest and admitted being impressed by Wagner's work.

${ }^{67}$ Matteo Mainardi, 'Il Catalogo Generale delle edizioni G.Ricordi \& C. Una prima analisi del gusto musicale di fine Ottocento', in: Sorba (ed.), op.cit., 221-42, 223. Franco Schnitzler, Mondo teatrale dell'ottocento. Episodi, testimonianze, musiche e lettere inedite (Naples 1954), 210. On Lucca's relationship with Verdi and Ricordi see Walker, op.cit., $122 \mathrm{f}$.

${ }^{68}$ Atti del Consiglio Comunale di Bologna (ACC), 29 March 1872; 31 May 1872 and 16 July 1873. ASCB, CA, 1876, X, 3, 4, 7408, letter of the mayor to Wagner (22 September 1876), and 11028, Report of the Deputazione to the mayor on the past autumn season, count Salina, 20 December 1876. ${ }^{69}$ Quoted in: Flora, op.cit, 121.

${ }^{70}$ Angelo Neumann, Erinnerungen an Richard Wagner (Leipzig 1907), 304.

${ }^{71}$ Ute Jung, Die Rezeption der Kunst Richard Wagners in Italien (Regensburg 1974), 171 sq. John Deathridge and Carl Dahlhaus, The New Grove Wagner (London and Basingstoke 1984), 65. Neumann's Ring cycle started with a performance in Berlin in 1881. Neumann, op.cit., $298 \mathrm{f}$. ${ }^{72}$ Levi, op.cit., 26.

${ }^{73}$ See for instance Monitore di Bologna, 4 October 1871; on Wagner and the Left also 28 August 1869. Bologna's Wagner Society was largely made up from the Democratic middle class: of the 135 members only 21 belonged to the nobility, seven of which were female. Cronaca Wagneriana, 1/4 (1893), 33. In the 1890s the Cronaca Wagneriana remembered Wagner as 'conspirator of 1848' and friend of Bakunin, who had lived the straitened existence of a political refugee in Switzerland. Comparing Wagner to an icon of the 'artiste engagé' like Emile Zola, the Cronaca Wagneriana reported the Frenchman's conviction that no composer could ever write greater music than Wagner. See 1/2 (1893), 9 f; and 2/6 (1894), 43; $1 / 4$ (1893), 27 f. Arturo Frizzi's popular 'Galleria di famiglia socialista' presents Wagner along with portraits of Hugo, De Amicis and Zola, as well as Marx, Lenin, Bissolati, Turati, Trotzky and Jaurès. See Mario Isnenghi, L'Italia in piazza. I luoghi della vita pubblica dal 1848 ai giorni nostri (Bologna 2004), 169 f. Almost half a century after Bologna's Lohengrin of 1871, the first Russian staging of Wagner after the October Revolution in 1918 was a 'futurist' production of Lohengrin by Fyodor Komissarzhevsky at the Theatre of the Workers Soviet, in which the director rejected the historicizing naturalism of conventional opera productions, proposing instead an abstract and timeless interpretation of the work: Rosamund Bartlett, Wagner and Russia (Cambridge 1995), 224. On the Italian reception of Wagner see in particular Miller, op.cit.; Jung, op.cit.; Adriana Guarnieri Corazzol, Tristano, mio Tristano: gli scrittori e il caso Wagner (Bologna 1988). Also Dietrich Mack and Martin Gregor-Dellin in Cosima Wagner, Die Tagebücher (Munich 1976), 12. Nunzio Pernicone, Italian anarchism, 1864-1892 (Princeton 1993), 88. See also Gramsci’s 
'Tendenze della cultura italiana', in: Antonio Gramsci, Quaderni del Carcere. Valentino Gerratana (ed.) (Turin 1975), Vol.2, $717 \mathrm{f}$.

${ }^{74}$ Gazzetta dell'Emilia, 30 October 1871.

${ }^{75}$ Gazzetta dell'Emilia, 3 November 1904.

${ }^{76}$ Weber, 'Wagner, Wagnerism, and Musical Idealism', op.cit., 29. This also explains the interest of the Milanese scapigliati in the composer and the Wagnerian references in D'Annunzio's work, particularly in his novels Trionfo della Morte (1894) and Il Fuoco (1898), even if the poet later distanced himself from Wagner's music. Gabriele D'Annunzio, La musica di Wagner e la genesi del 'Parsifal' (Florence 1914). For D’Annunzio's view of Wagner see Guarnieri Corazzol, op.cit., 7 sq. Also Nachum Schoffman, 'D'Annunzio and Mann: Antithetical Wagnerisms', The Journal of Musicology, 11/4 (1993), 499-524. Galvan, 'Thomas Mann in Italia.', op.cit. Miller, 'Wagnerism, Wagnerians and Italian Identity', op.cit., 188-91. Franca Angelini, Teatro e spettacolo nel primo novecento (Rome and Bari 1988), 10. Jung, op.cit., 121, 387 sq.

${ }^{77}$ In addition to the bibliography cited in the previous chapter see in particular Hervé Lacombe, The Keys to French Opera in the Nineteenth Century (Berkeley and Los Angeles: 2001). Steven Huebner, French Opera at the Fin de Siècle: Wagnerism, Nationalism, and Style (Oxford 1999). Michael Strasser, 'The Société Nationale and Its Adversaries: The Musical Politics of L'Invasion germanique in the 1870s', Nineteenth Century Music, 24/3 (2001), 225-51, 237 f. Large and Weber (eds), op.cit.

${ }^{78}$ See for instance the debates analysed in Roccatagliati, op.cit. Körner, Politics of Culture, op.cit., chpt.9. Furthermore Deathridge and Dahlhaus, op.cit., 92 sq.

${ }^{79}$ Gazzetta Musicale di Milano, 10 April 1859, reprinted 12 Jan 1862

${ }^{80}$ Rivista Bolognese di Scienze, Lettere, Arti e Scuole, Vol. $2 / 4$ (1868), 331 and Vol.2/6 (1868), 556.

${ }^{81}$ I refer here to the concept of historical time introduced by Reinhart Koselleck, Vergangene Zukunft. Zur Semantik geschichtlicher Zeiten (Frankfurt/M. 1989). Deathridge and Dahlhaus, op.cit., 114.

${ }^{82}$ Camera dei Deputati, 6 February 1873, quoted in: Ernesto Masi, Camillo Casarini. Riccordi contemporanei (Bologna 1875), 185-188.

${ }^{83}$ Luigi Maniscalco Basile, Storia del Teatro Massimo di Palermo (Florence 1984), 201.

${ }^{84}$ Cronaca Wagneriana, Vol.1/3 (1893). Giancarlo Rostirolla, Wagner in Italia (Turin 1982).

${ }^{85}$ Il Resto del Carlino, 18 May 1885. Cronaca Wagneriana, Vol.1/1 (1893), 4. Levi, op.cit., 24 f. Vatielli, op.cit., 47.

${ }^{86}$ ASCB, CA, 1913, X, 3, 4, 8604, 8899, letter of the mayor to the German consul, 4 May 1913.

${ }^{87}$ Alfonso Rubbiani, quoted in: Mario Fanti, 'Alfonso Rubbiani: il restauro, la politica e la poesia', Strenna Storica Bolognese, 31 (1981), 113-131, 129. On the Bach-Renaissance in Germany see Celia Applegate, Bach in Berlin. Nation and Culture in Mendelssohn's Revival of the St Matthew Passion (Ithaca and London 2005). See also Walter Frisch, German Modernism. Music and the Arts (Berkeley 2005), 144-49.

${ }^{88}$ Somigli and Moroni (eds), op.cit., 10.

${ }^{89}$ Valebona, op.cit., 205, 232. Maniscalco Basile, op.cit., 205.

${ }^{90}$ Gatti, op.cit., 235, 246.

${ }^{91}$ ACC, 30 December 1911. In 1909 the opera had been on the programme in Milan and Genoa.

${ }^{92}$ La Traviata, Rigoletto, Aida, Don Carlos, I Lombardi. Twice Lohengrin, Meistersinger, Siegfried, Rheingold, twice Tristan, Walküre, Götterdämmerung, Tannhäuser, Parsifal. On the reception of Puccini see Wilson, op.cit.

${ }^{93}$ Gatti, op.cit., 182.

${ }^{94}$ Lugo presented Carmen in 1895 and 1908, the Massimo in Palermo in 1902 and 1908. Rossi, op.cit., 65, 72. Maniscalco Basile, op.cit., 202.

${ }^{95}$ Brian Rees, Camille Saint-Saëns. A Life (London 1999), 317. Maniscalco Basile, op.cit., 204.

${ }^{96}$ Didier Francfort, 'Le crepuscule des Héros. Opéra et Nation après Verdi', Mélanges de l'Ecole Française de Rome. Italie et Méditerranée, Vol.117/1 (2005), 269-93, 271. Francesca Socrate, 'Commedia borghese e crisi di fine secolo', in: Sorba (ed.), op.cit., 21-60, 41. Wilson, op.cit., 18. Massenet was himself profoundly influenced by Wagner: Steven Huebner, 'Massenet and Wagner: Bridling the influence', Cambridge Opera Journal, 5/3 (1993), 223-38. On Wagnerism in France also Huebner, French Opera at the Fin de Siècle, op.cit., 76 f. For an excellent analysis of the complexities of the debate in France see Strasser, op.cit.; also Philipp Ther, In der Mitte der Gesellschaft.

Operntheater in Zentraleuropa 1815-1914 (Munich 2006), 266. On 'nationalisation' ibid., 18, 121 sq. Michael C. Tusa, 'Comopolitanism and the National Opera: Weber's Der Freischütz', Journal of Interdisciplinary History, Vol.36/3 (2006), 483-506. Koen Buyens, 'Muziek en natievorming in België: het muziekleven te Brussel, 1830-1850', Bijdragen en Medelingen betreffende de geschiedenis der Nederlanden, Vol.121/3 (2006), 393-417. 
${ }^{97}$ Sholem Perlmutter, Yiddishe Dramaturgen un Teater-Compositors (New York 1952), 104-106. Fred Somkin, 'Zion's harp by the East River: Jewish-American Popular Songs in Columbus's Golden Land, 1890-1914', Perspectives in American History (N.S.), Vol.2 (1985), 183-220, 195.

${ }^{98}$ Catharine Macedo, 'Between opera and reality: the Barcelona Parsifal', Cambridge Opera Journal, Vol.10/1 (1998), 97-109, 101. Prague even offered two Parsifals on the first of January, one in German, the other in Czech. Ther, op.cit., 339.

${ }^{99}$ See Filippo Tommaso Marinetti, 'Down with the Tango and Parsifal. Futurist letter circulated among cosmopolitan women friends who give tango-teas and Parsifalize themselves', 11 January 1914, in: Filippo Tommaso Marinetti, Selected Writings. R. W. Flint, ed. (London 1972), 69-72. Also Miller, 'Wagnerism, Wagnerians and Italian Identity', op.cit., 194 f. On Papini also Walter L. Adamson, Avant-Garde Florence: from modernism to fascism (Cambridge, Mass. 1993).

${ }^{100}$ Francesco Balilla Pratella, Musica Italiana. Per una cultura della sensibilità musicale italiana (Bologna 1915). Antonio Castronuovo and Sante Medri (eds), Il futurismo a Lugo (Imola 2003).

${ }^{101}$ Edward J. Dent, Ferruccio Busoni. A Biography (London 1974), 212. Reinhard Kannonier, Bruchlinien in der Geschichte der modernen Kunstmusik (Vienna 1987), 41. Matthias Henke, 'Bewegtheit und Bewegung', in: Siegfried Mauser and Mathias Schmidt (eds) Geschichte der Musik im 20. Jahrhundert: 1900-1925 (Laaber 2005), 227-253, 241 f. Antony Beaumont, Busoni the composer (London 1985), 136. Marc-André Roberge, Ferruccio Busoni. A Bio-Bibliography (New York 1991), $16,21,23 \mathrm{f}$.

${ }^{102}$ Pfitzner responded to Busoni's new aesthetic with a polemical pamphlet: Hans Pfitzner, Futuristengefahr. Bei Gelegenheit von Busoni's Ästhetik (Leipzig and Munich 1917).

${ }^{103}$ Bossi was Busoni's predecessor as director of Bologna's Liceo Musicale. Further to the works mentioned above Mahler conducted Mendelssohn's Italian symphony. See Zoltan Roman, Gustav Mahler's American Years 1907-1911. A Documentary History (Stuyvesant 1989), 456.

${ }^{104}$ Günter Berghaus, Futurism and Politics. Between Anarchist Rebellion and Fascist Reaction, 19091944 (Providence 1996), 58.

${ }^{105}$ Esra Akcan, 'Towards a Cosmopolitan Ethics in Architecture: Bruno Taut's Translation out of Germany', New German Critique, Vol.99, 2006, 7-39, 9.

${ }^{106}$ Ernst Bloch, Erbschaft dieser Zeit (Frankfurt/M. 1985). Peter I. Barta (ed.), Metamorphoses in Russian Modernism (Budapest and New York 2000). Jennifer Jenkins, Provincial Modernity: local culture \& liberal politics in fin-de-siècle Hamburg (Ithaca 2003). For the concepts of Multiple and Alternative Modernities see Ruth Ben-Ghiat, Fascist Modernities. Italy, 1922-1945 (Berkely 2001). Roger Griffin, Modernism and Fascism. The Sense of a Beginning under Mussolini and Hitler (Basingstoke 2007), 2, 6. Nicola Miller, Reinventing Modernity in Latin America: Intellectuals Imagine the Future (New York and London 2007). 